\title{
The genetic diversity and reproductive dynamics of sandalwood in Gunung Sewu (Java, Indonesia) in 2012-2019: designing conservation strategies in a continuous versus fragmented landrace
}

\author{
YENI W.N. RATNANINGRUM ${ }^{1,2, v}$, SAPTO INDRIOKO ${ }^{2, v v}$, AMELLITA KARRIN" ${ }^{3, v v v, ~}$ \\ ADITYA KURNIAWAN ${ }^{3, \vee v \vee, ~ A N G G I ~ D . C . ~ P U T R I ~}{ }^{3, \vee v \vee}$ \\ ${ }^{1}$ Forest Seed Science Laboratory, Faculty of Forestry, Universitas Gadjah Mada. Jl. Agro No. 1, Bulaksumur, Sleman 55281, Yogyakarta, Indonesia. \\ Tel./fax.: +62-274-550541. `email: yeni.wnr@ugm.ac.id; yeniratnaningrum@gmail.com \\ ${ }^{2}$ Forest Tree Improvement Laboratory, Faculty of Forestry, Universitas Gadjah Mada. Jl. Agro No. 1, Bulaksumur, Sleman 55281, Yogyakarta, \\ Indonesia. Tel.: +62-274-550543, "vemail: sindrioko@ugm.ac.id \\ ${ }^{3}$ Department of Silviculture, Faculty of Forestry, Universitas Gadjah Mada. Jl. Agro No. 1, Bulaksumur, Sleman 55281, Yogyakarta, Indonesia

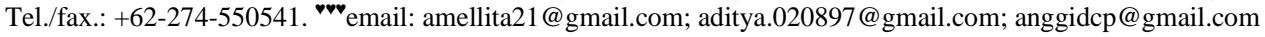

Manuscript received: 30 November 2020. Revision accepted: 15 July 2021.

\begin{abstract}
Ratnaningrum YWN, Indrioko S, Karrin A, Kurniawan A, Putri ADC. 2021. The genetic diversity and reproductive dynamics of sandalwood in Gunung Sewu (Java, Indonesia) in 2012-2019: designing conservation strategies in a continuous versus fragmented landrace. Biodiversitas 22: 3219-3229. This research aimed to compare the dynamics of the genetic diversity, mating systems, and reproductive outputs of the most fragmented (Bejiharjo) and continuous (Bleberan) sandalwood landraces in Gunung Sewu in the flowering periods of 2012-2019. Among the different sandalwood landraces found in Gunung Sewu, Bejiharjo has the highest levels of santalol; unfortunately, this landrace also requires the most attention because of heavy habitat fragmentation resulting from overexploitation, urbanization, and cave-tourism activities. Compared with Bejiharjo, Bleberan demonstrated a wider genetic base and greater outcrossing. Mature and flowering individuals in Bejiharjo decreased from 2012 to 2019 as fragmentation increased, particularly in 2019, during which extreme individual reduction due to illegal logging and land conversion was noted. Recent years consisted of more-clonalized stands, as indicated by the finding of fewer distinct genotypes and higher clonality rates. Increases in clonality and narrowing of the genetic base over time increased selfing rates and reduced offspring heterozygosity and seedling recruitment. The dynamics of genetic diversity in Bleberan, which was relatively undisturbed, appeared to be highly affected by fluctuations in the number of parental genetic bases (i.e., flowering parents) in each flowering season. Some parents bore flowers in one flowering season but remained in a vegetative state in the following season. This irregularity of flowering individuals caused fluctuations in actual population size, resulting in a different genetic base, mating system, and reproductive outputs in every season. All six loci (i.e., Dia-1, Dia-2, Est-1, Est-2, Est-3, and Skd-1) examined in Bleberan are polymorphic sites, and no missing alleles were noted in any of the observation years. Est-2 was monomorphic in Bejiharjo, where rare and missing alleles were more apparent, particularly at the seedling level. Genetic differentiation over time was observed between Bejiharjo and Bleberan, and increased fragmentation was noted in Bejiharjo. The migration rate between these two landraces also decreased over time. Focusing on maintaining the reproductive and genetic processes of each population by implementing different strategies based on the genetic base, mating systems, and degree of fragmentation and clonality of the landrace is recommended.
\end{abstract}

Keywords: Bejiharjo, Bleberan, Gunung Sewu, fragmented vs. continuous landraces, sandalwood

\section{INTRODUCTION}

The continuous fragmentation of tropical forests is considered a main threat to biodiversity conservation (Moreira et al. 2015). Habitat fragmentation directly results in three main consequences for plant populations: (i) habitat loss, (ii) population size reduction, and (iii) increased spatial isolation between remnant populations (Klank et al. 2012). In turn, forest fragmentation may negatively affect gene flow, reproduction, and genetic diversity (Moreira et al. 2015). Gene flow through pollen and seeds may be inhibited, inbreeding rates may increase, and the level of isolation in fragmented populations may be exacerbated. Ongoing fragmentation events can create a disjunct population in which gene flows are disrupted by physical and/or genetic barriers (Sampson et al. 2016).
Habitat fragmentation may result in bottleneck effects because the remnant parents experience a narrow genetic base. Compared with that in continuous populations, the effect of genetic selection is more apparent in disjunct ones (Garfì et al. 2013; Moreira et al. 2015) because the enhanced bottleneck effect and genetic drift could result in the loss of more alleles (Bottin et al. 2007). Thus, reductions in genetic diversity may be attributed to increased isolation, reductions in population size, and alterations in the mating system favoring inbreeding (Young et al. 2000). Furthermore, low-genetic variation, which is commonly associated with small population size and high levels of inbreeding, could reduce plant fitness and reproductive success (Klank et al. 2012; Moreira et al. 2015). 
Threatened and fragmented plant species can maintain their genetic diversity only if the genetic base is wide and the mating preference is outcrossing (Bradbury et al. 2015). These conditions have significant implications in designing conservation efforts and are the main issues in sandalwood, which has been proven to have strong ability for clonal reproduction via root suckers (da Silva 2016; Ratnaningrum et al. 2015, 2017), partial self-compatibility (Ratnaningrum et al. 2017), and mating system alterations to accommodate more inbreeding under isolated conditions (Indrioko and Ratnaningrum 2015; Ratnaningrum et al. 2015). Compared with non-fragmented populations, a fragmented sandalwood population is more likely to become extinct because of restricted gene flow, increased clonality, genetic base narrowing, genetic diversity reduction, and mating system alterations. Thus, conservation efforts for threatened landraces depend on the level of understanding of each of these factors (Lhuillier et al. 2006; Bottin et al. 2007; Rao et al. 2007; Dani et al. 2011; Ratnaningrum et al. 2017; Sandeep et al. 2019).

Sandalwood is a sub-shrub flowering perennial that grows in semi-arid and arid regions (Rao et al. 2007; da Silva et al. 2016). It is mostly reproduced by root suckers, and the sprouts develop from horizontal roots (Warburton et al. 2000; Lhuillier et al. 2006; Dani et al. 2011; da Silva et al. 2016). Sandalwood produces a large number of flowers that are generally pollinated by insects (Tamla et al. 2012). In Indonesia, sandalwood flowers twice a year, at the beginning of the dry and rainy seasons, and has a flowering period of 4-5 months. The sexual organs of the shrub are dichogamous, and the pollen matures 2 days before stigma receptivity (Ratnaningrum et al. 2018). The mating preference of sandalwood is outcrossing with high self-incompatibility (Rao et al. 2007; Dani et al. 2011; Tamla et al. 2012; Indrioko and Ratnaningrum 2015; da Silva et al. 2016), although $S$. accuminatum (Warburton et al. 2000) and S. album (Suma and Balasundaran 2003; Ratnaningrum et al. 2018) are partially self-compatible. Fruit production is very low despite the presence of abundant flowers. Previous studies reported the high pollen fertility of $S$. album in India (88.40\%; Suma and Balasundaran 2003) and moderate pollination effectiveness of S. album in Java Island (10\%-40\%; Ratnaningrum et al. 2018). Unfortunately, very low reproductive success rates ranging from less than $5 \%$ in fragmented or isolated populations (Byrne et al. 2003; Indrioko and Ratnaningrum 2015; Sindhu-Vereendra and Anantha-Padmanabha 1996; Warburton et al. 2000) to approximately $20 \%$ in larger populations (da Silva et al. 2016; Ratnaningrum et al. 2018) have been reported.

Islands in the eastern portion of Indonesia are considered the origin of all sandalwood species found worldwide (da Silva 2016; Harbaugh and Baldwin 2007; Rao et al. 2007). Santalum album Linn., hereinafter referred to as sandalwood, is an economically important species because its heartwood, which contains $20-50 \% \alpha$ santalol and $10-36 \% \beta$-santalol, is broadly used for wood carvings and religious and medicinal purposes. The price of sandal heartwood was US\$9,400 ton ${ }^{-1}$ in 1990 and increased to US\$150,000 ton ${ }^{-1}$ in 2014 (da Silva et al.
2016). Sandalwood oil features a strong unique fragrance and is used in cosmetics, perfumes, and aromatherapeutic supplies. Some research indicates that the product may have anti-melanoma compounds (Rao et al. 2007; da Silva et al. 2016). The price of sandalwood oil was US $\$ 1,250 \mathrm{~kg}^{-}$ 1 in 2006 (Harbaugh dan Baldwin 2007) and exceeded US $\$ 5,000 \mathrm{~kg}^{-1}$ in 2015 (da Silva et al. 2016). The IUCN Red List first considered sandalwood as a Vulnerable species because of its extensive habitat degradation and loss (IUCN 1994). A re-inventory in 2012 confirmed a $100 \%$ reduction in population size within less than three generations (equal to 10 years) (Ratnaningrum et al. 2017). Therefore, the extinction status of the plant should have been escalated in the IUCN Red List (IUCN 2009). Previous studies reported a low-genetic base, high clonality, and fragmentation as the main factors causing heterozygosity reduction and inbreeding, which, in turn, result in the reproductive failure of sandalwood in Indonesia (Indrioko and Ratnaningrum 2015; Ratnaningrum et al. 2017). Similar findings have been widely reported for $S$. insulare in the Pacific islands (Lhuillier et al. 2006), S. austrocaledonicum in New Caledonia (Bottin et al. 2007), S. lanceolatum in Australia (Warburton et al. 2000), S. spicatum in Western Australia (Byrne et al. 2003), and S. album in Peninsular (Rao et al. 2007) and Southern (Dani et al. 2011) India.

Considering the rapid degradation of their native habitat in southeastern parts of Indonesia, the development of new sandalwood landraces in Gunung Sewu is a promising prospect for conservation efforts targeting the species. Gunung Sewu Global Geopark Network, which is located in Java Island, in the central region of the Indonesian archipelago, is a mountainous limestone zone measuring approximately $1300 \mathrm{~km}^{2}$ in width. The ancient geological processes of this network include volcanic activities, tectonic movement, and seawater erosion, all of which began approximately 1.8 million years ago and endowed the area with various landscape structures, each of which differ in terms of elevation, altitude, site characters, and microclimate conditions. Gunung Sewu was recently divided into three zones: the Northern Zone, which consists of several mountainous groups in highland areas and cave landscapes in lowland areas; the Middle Zone, which includes basins, cliffs, waterfalls, and riparian catchment areas; and the Southern Zone, which is derived from karst with uplift and downlight formations. Most sandalwood landraces in Gunung Sewu are concentrated in the Middle Zone. Some landraces in Gunung Sewu are naturally isolated because of the specific landscape types of the area, while others are fragmented and clonalized because of natural hazardous and anthropogenic disturbances. Some landraces included in conservation areas are derived from more diverse genotypes (Ratnaningrum et al. 2015, 2017).

Previous studies comparing several landraces in Java Island and provenances in Eastern Indonesia revealed that the number of flowering trees (i.e., the effective population size) is not the most important factor in maintaining the genetic diversity and reproductive and population fitness of sandalwood populations. Reproductive and genetic processes are strongly affected by parental clonality and 
genetic base, which, in turn, remarkably determine mating systems and affect reproductive outputs. Populations that are more clonalized and show lower diversity are more likely to become inbreeders than those that do not (Ratnaningrum et al. 2015, 2017). In such populations, most flowering trees share the same parent and, therefore, are genotypically identical. Hence, even in the presence of abundant flowering trees, flowers, and pollinators, geitonogamy dominates the mating system, resulted in a high selfing rate.

Among the landraces found in Gunung Sewu, the Bejiharjo landrace has attracted increased attention for several reasons. The Bejiharjo landrace is derived from dry-rocky hills below which ground-rivers and caves may be found. These features contribute to the relative isolation of this sandalwood variety. Urbanization, illegal logging, and cave-tourism activities since the 1990s have contributed to the ongoing fragmentation of this landrace. A sandalwood landrace recently discovered in Bejiharjo is the remnant of a plantation that had been established in the 1970s using seeds from Nglipar Sub-district, an older landrace. Previous Bejiharjo landraces seem to have a wider genetic base; hence, founder effects only exist at very low levels (Indrioko and Ratnaningrum 2015). Heavy exploitation in the 1980s, followed by landscape modification for urban activities and cave tourisms in the early 2000s, resulted in the extensive fragmentation of this landrace (Ratnaningrum et al. 2017). Today, remnant stands exist in very small fragmented groups and grow in a dispersed manner on dry-rocky hills above caves and ground-rivers. Regenerated sandalwood in Bejiharjo is largely derived from root suckers, and its mating system has been altered to become more inbred, a condition that can cause extreme reductions in offspring genetic diversity. Limited seed sets after flowering and pollination result in less seedling recruitment because of inbreeding depression (Ratnaningrum et al. 2015, 2017; Ratnaningrum and Kurniawan 2019). Most conservation efforts consider this landrace as a priority because sandals of the Karangmojo group (including Bejiharjo) are among those with higher levels of santalol (Haryjanto et al. 2017).

In contrast to the Bejiharjo landrace, the Bleberan landrace shows a very wide genetic base and is highly outcrossed (Ratnaningrum et al. 2015; 2017); thus, it has been recommended as a seed source for planting programs (Fathin and Ratnaningrum 2018). Bleberan is considered a continuous population because it exists in the middle of other landraces and ex situ conservation sites, such as Wanagama, Watusipat, Banyusoco, and Mulo, all of which are within less than $5 \mathrm{~km}$ of each other. These sites share the same river, the Oya River, a known agent of seed dispersal. Some sites have higher heterozygosity levels, outcrossing rates, and pollen migration rate (Ratnaningrum et al. 2015, 2017). High levels of gene flow from seeds and pollen in this area may be attributed to dispersal by pollinators (Fathin and Ratnaningrum 2018), birds, and the streamflow of the river (Ratnaningrum et al. 2017).

A broad range of biochemical and molecular markers, including isoenzymes or allozymes, random amplified polymorphic DNAs (RAPDs), random fragment length polymorphisms (RFLPs), direct amplification of minisatellite DNAs (DAMDs), and simple sequence repeats, have been used to analyze the characteristics of Santalum. These markers offer different advantages and disadvantages and, therefore, are used in different conditions (da Silva et al. 2017). Isozyme markers are widely used because they require small amounts of plant materials, the alleles show simple Mendelian inheritance and codominant expression, the comparisons of homologous loci among populations are straightforward, and the markers cost less than other genetic markers. However, isozymes are limited by bias in some sample genomes and the small number of expressed alleles and loci because only genes encoding soluble enzymes can be observed. While several authors have suggested the use of more than one marker (Torres et al. 2003; da Silva et al. 2017), isozymes and RAPDs generally give similar results in many sandalwood studies (Warburton et al. 2000; Dani et al. 2011; da Silva et al. 2016, 2017). Moreover, in many cases, different genotypes are indistinguishable when using RAPDs but clearly detected when using allozymes (Warburton et al. 2000). RFLPs with 7 chloroplasts and 21 nuclear probes are insufficient to differentiate among Indian and Timorese S. album in Western Australia. By contrast, 10 polymorphic isozyme loci are able to distinguish S. album in India, and 3 isozymes with 6 polymorphic loci are sufficient to detect the same species in Indonesia (da Silva et al. 2017). Some similar works including isoenzyme-only analysis revealed high levels of diversity in sandalwood (Angadi et al. 1993; Brand 1994; Suma and Balasundaran 2003; Rao et al. 2007; Ratnaningrum et al. 2015; 2017). Thus, isozymes are among the best options in estimations of the genetic structures of sandalwood. However, more samples are needed to overcome the current limitations, and the sampling method must represent the complete genome of the population (Young et al. 2000; da Silva et al. 2017).

Because sandalwood individuals in Gunung Sewu are high outcrossers, fragmentation and clonality may be expected to reduce their gene flow, genetic base, and outcrossing rate, consequently reducing the genetic diversity and reproductive outputs of the landraces (Ratnaningrum et al. 2015, 2017; Ratnaningrum and Kurniawan 2019). The present study aimed to compare the dynamics of the population structures, genetic diversity, mating systems, and reproductive outputs of the most fragmented (Bejiharjo) and continuous (Bleberan) sandalwood landraces in Gunung Sewu in the flowering periods of 2012-2019.

\section{MATERIALS AND METHODS}

\section{Study sites}

This study focused on only 2 of the 12 sandalwood landraces in Gunung Sewu of Gunungkidul District, Yogyakarta Province, Indonesia, namely, Bejiharjo, the most disturbed landrace, and Bleberan, the fittest landrace (Figure 1). 
Bejiharjo Village $\left(07^{\circ} 55^{\prime} \mathrm{S} ; 110^{\circ} 39^{\prime} \mathrm{E} ; 150-180 \mathrm{~m}\right.$ asl.) is located in Karangmojo Sub-district. Its landscape is derived from the Sambipitu Formation in the lowland region of the Northern Zone of Gunung Sewu. Bejiharjo covers 9 ha of dry-rocky hills below which caves and ground-rivers may be found and represents a dryland ecosystem under the strong $A w$ of the Schmidt and Fergusson climatic type. This dry site experiences extremely low air humidity $(31.94 \%)$ and rainfall $(1,511$ $\mathrm{mm}$ annually over less than 6 rainy months), high air temperatures $\left(40.51^{\circ} \mathrm{C}\right)$, and low soil moisture $(21.32 \%)$. Soils in Bejiharjo are composed of red mediterrans and black grumosols, with rocks derived from limestones, and mostly have a shallow solum. The recent landrace is a remnant of plantations that had been established in the 1970s using seeds collected from Nglipar, an older landrace. This landrace exists in very small fragmented groups and grows in a dispersed manner on dry-rocky hills. Younger stands are largely derived from root suckers. The landrace is associated with the natural regeneration of cajuput and acacia from plantations nearby, together with dryland herbs, such as grasses and Eupatorium sp. The Bejiharjo landrace is the most isolated landrace on the island because it is surrounded by dry-rocky hilly landscapes with caves and ground-rivers. Studies indicate that it is separated from other landraces by $25-40 \mathrm{~km}$.
Bleberan Village $\left(7^{\circ} 50^{\prime} \mathrm{S} ; 110^{\circ} 50^{\prime} \mathrm{E} ; 150-170 \mathrm{~m}\right.$ asl.) in Playen Sub-district, is part of the Wonosari Basin Formation, which is located in the Middle Zone of Gunung Sewu. Bleberan is a catchment area of the subterranean river, the Oya River. It represents a tropical lowland ecosystem and is characterized by a lowland basin landscape that receives abundant rainfall $(2,346 \mathrm{~mm}$ annually over 6 rainy months). Hence, even in the intermediate regions of the $A m$ and $A w$ climatic zones with high temperature $\left(34.37^{\circ} \mathrm{C}\right)$ and light intensity, the area maintains high air humidity $(58.36 \%)$ and soil moisture $(27.33 \%)$. The Bleberan landrace covers 52.9 ha of hills, river, and falls. The soils are composed of red mediterrans and black grumosols, with rock derived from limestones, and mainly have a deep solum. The occurrence of sandalwood along the riparian sides of the Oya River was first documented in the 1970s. Recent research revealed the wide dispersion of the species from along the catchment area to the hills nearby, which is mostly associated with tropical lowland forest vegetation, such as mahogany, teak, cajuputi, and acacia. Bleberan is considered a continuous population because it is connected to many other sandalwood landraces and nearby ex situ conservation areas that share the same river.

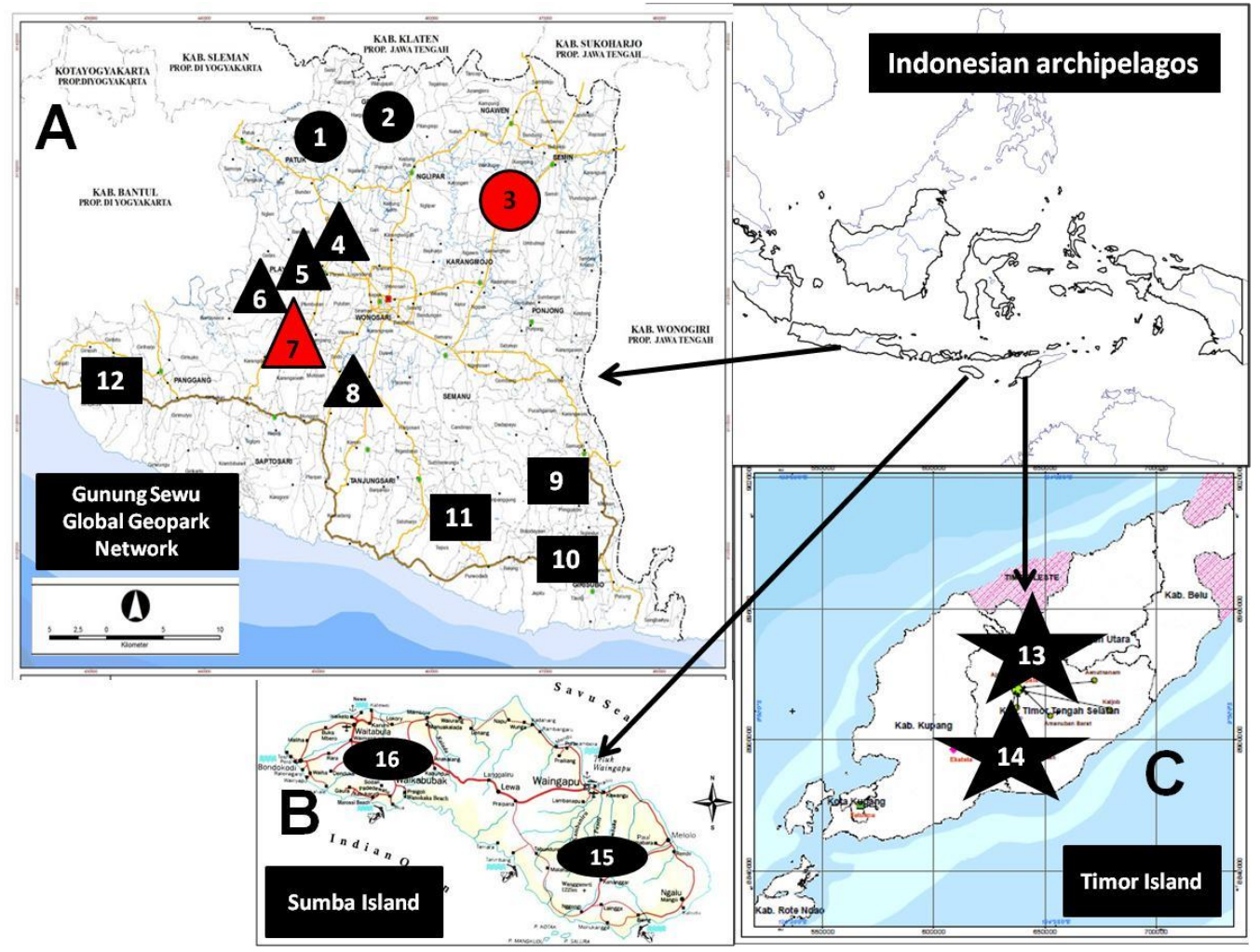

Figure 1. Distribution of sandalwood populations and landraces in Indonesia. A. Groups of sandalwood in Gunung Sewu, Java Island. The first sandalwood group in the Northern Zone consists of the Nglanggeran (1), Sriten (2), and Bejiharjo (3) landraces. The second sandalwood group in the Middle Zone consists of the Bunder (4), Wanagama (5), Banyusoco (6), Bleberan (7), and Mulo (8) landraces. The third sandalwood group in the Southern Zone consists of the Petir-Semugih (9), Botodayakan (10), Panggang (12), and Tepus (11) landraces. The landraces in the Northern Zone are marked by circles, those in the Middle Zone are marked by triangles, and those in the Southern Zone are marked by squares. This study investigates the Bejiharjo (3) and Bleberan (7) landraces, which are marked in red. B. Remnants of sandalwood populations in Sumba Island: the Waingapu and Eastern Sumba (15) and Waikabubak and Western Sumba (16) populations. C. Remnants of sandalwood populations in Timor Island: the Soe (14) and Netpala (13) populations. 


\section{Study species}

Sandalwood in Bejiharjo was first planted in the 1970s using materials collected from Nglipar (The Head of RPH Gelaran; pers. comm.), as proven by the genetic similarity between these two sites (Ratnaningrum et al. 2015; 2017). Because this landrace appears to have a wide genetic base, founder effects are not particularly obvious (Ratnaningrum et al. 2015). Fragmentation began in the 1980s because of illegal logging and heavy exploitation and continued up to the year 1998, during which massive riots resulting in the loss of many adult individuals were recorded. A study published in 2012 observed heterozygosity reduction in existing mature trees compared with that in the parents of the previous generation; the sandalwood seedlings also showed considerable heterozygosity reduction (Indrioko and Ratnaningrum 2015). Modification of landscapes for urban purposes, river-tubing, and caving eco-tourism have promoted the fragmentation of the landrace. Many mature plants growing in small fragmented groups of stands are derived from root suckers that share the same parent. A study in 2014 reported that intense clonality increases selfing and reduces genetic diversity, particularly at the seedling level (Ratnaningrum et al. 2015). Such fragmentation became more apparent in 2016-2017, with the loss of nearly half of all remnant trees due to land conversion. During this period, the genetic base narrowed, the mating system was dominated by selfing, and no seeds were formed following mass flowering (Ratnaningrum and Kurniawan 2019).

Sandalwood was first documented in Bleberan in the 1970 s as a natural regeneration growing along the catchment area of the Oya River from unknown seed sources (The Head of RPH Menggoran; pers. comm.). A later study indicated that the seeds may have come from Wanagama, a nearby ex situ conservation area established in 1964 (Ratnaningrum et al. 2017). The genetic diversity of the species has increased over the years with the appearance of more sandalwood landraces in the surrounding areas, such as Mulo (1970), Watusipat (1990), and Banyusoco (2000) landraces. These sites have a high level of heterozygosity, outcrossing rates, and pollen migration rates (Ratnaningrum et al. 2015, 2017). Extensive gene flow among seeds and pollen has been detected between Bleberan and Wanagama, likely because of dispersal by pollinators (Fathin and Ratnaningrum 2018), birds, and the streamflow of the river (Ratnaningrum et al. 2017). Previous studies reported relatively constant trends of heterozygosity, mating systems, and reproductive outputs in sandalwood in Bleberan despite its small population size and irregular flowering pattern (Ratnaningrum et al. 2015, 2017; Ratnaningrum and Kurniawan 2019).

\section{Isozyme-based genetic diversity measurements}

Temporal variations in genetic diversity were estimated for the years 2012, 2014, and 2019, and the genetic diversity within each year was measured between two generations (i.e., parents and seedlings), using isozyme analysis. Differences in the number of samples in each site and in every observation year were attributed to differences on the proportion of reproductively versus vegetatively propagated individuals (Table 1). Bejiharjo is highly clonalized and largely derived from vegetatively propagated individuals of the same parent. Therefore, despite its large quantity, finding individuals of different siblings for this work was challenging. By contrast, despite the small population size of the landrace, most of the individuals in Bleberan are derived from sexual propagation. Hence, samples were obtained from many individuals of different siblings to take into account the wide range of genotypes representing most of the genome of Bleberan.

Juvenile leaves were sampled from flowered individuals and seedlings. The samples were placed in small tubes, covered, and frozen in ice packs for allozyme extraction and electrophoresis. A previous study observed three polymorphic enzymes, namely, esterase (Est; E.C. 3.1.1.), diaphorase (Dia; E.C. 2.6.4.3.), and shikimate dehydrogenase (Sdh; E.C. 1.1.1.25.) (Indrioko and Ratnaningrum 2015). Interpretable zymogram phenotypes were found for only six loci, namely, esterases Est-1, Est-2, and Est-3; diaphorase Dia-1 and Dia-2; and the shikimate dehydrogenase $S k d-1$. Vertical polyacrylamide gel electrophoresis was conducted following the method of David-Ornstein (Seido 1993). The samples were homogenized in modified extraction buffer and centrifuged at $15,000 \mathrm{rpm}$ and $4{ }^{\circ} \mathrm{C}$ for 15 minutes. The supernatant solution was loaded onto polyacrylamide vertical slab gels and electrophoresed at $220 \mathrm{~V}$ and $200 \mathrm{~mA}$ for 180 minutes at $4{ }^{\circ} \mathrm{C}$. Staining solution was applied to the gels, and the stained allozyme gels were genetically interpreted.

The frequency and distribution of each allele and genotype in each allozyme locus were counted following the method of Seido (1993). The proportion of heterozygote genotypes was calculated for each locus and presented as a percentage of the observed heterozygosity $\left(\mathrm{H}_{\mathrm{o}}\right)$. The expected heterozygosity $\left(\mathrm{H}_{\mathrm{e}}\right)$ was assessed for each locus and overall loci in Hardy-Weinberg equilibrium following the formula: $H_{e}=1-\Sigma p_{i}^{2}$, where $p_{i}$ is the-i's number of allele frequency of a given population. Total population heterozygosity $\left(\mathrm{H}_{\mathrm{T}}\right)$ was determined following the formula: $\mathrm{H}_{\mathrm{e}}=1-\Sigma \mathrm{p}_{\mathrm{it}}{ }^{2}$, where $\mathrm{p}_{\mathrm{it}}$ is the-i's number of allele frequency of the population in total.

Mating systems were represented by the fixation index $\left(F_{i s}\right)$, which was calculated following the formula: $F_{i s}=1-$ $\mathrm{H}_{\mathrm{o}} / \mathrm{H}_{\mathrm{e}} . \mathrm{F}_{\mathrm{is}}$ represents the inbreeding coefficient, which refers to the extent of deviation from the expected frequencies under Hardy-Weinberg equilibrium. A mating system in a population is considered random when $F_{\text {is }}=0$, outcrossing when $F_{\text {is }}$ is negative, and inbreeding when $F_{\text {is }}$ is positive (Seido 1993; Young et al. 2000).

Genetic differentiation was assessed by evaluating the genetic diversity between populations $\left(\mathrm{D}_{\mathrm{ST}}\right)$, which was calculated by reducing $\mathrm{H}_{\mathrm{T}}$ to the heterozygosity within a population $\left(\mathrm{H}_{\mathrm{s}}\right)$. The mean proportion of total gene diversity at polymorphic loci due to differences between populations $\left(\mathrm{G}_{\mathrm{ST}}\right)$ was calculated by dividing $\mathrm{D}_{\mathrm{ST}}$ by $\mathrm{H}_{\mathrm{T}}$. The migration rate $\left(\mathrm{N}_{\mathrm{e}} \mathrm{m}\right)$, which represents the level of previous gene flow contributing to the recent population, 
was calculated following the formula: $\mathrm{N}_{\mathrm{e}} \mathrm{m}=\left(1 / \mathrm{G}_{\mathrm{ST}}-1\right) / 4$ (Frankham et al. 2002).

\section{Estimation of the effective population size, seedling recruitment, and extent of clonality}

A $100 \%$ inventory of the flowering individuals for each year considered in this study was conducted. The total number of individuals, including adults and seedlings, was counted. The effective population size refers to the number of flowering individuals divided by the total number of adult individuals, and natural offspring recruitment refers to the number of seedlings in a population (Frankham et al. 2002).

Total numbers of flowering trees and flowering trees with distinct genotypes for each year considered in this study were counted to estimate the clonality level of the landraces. Clonality was measured following the formula (Bradbury et al. 2015): degree of clonality $=[1-($ number of flowering trees with distinct genotypes / total number of flowering trees) $] \times 100 \%$.

\section{RESULTS AND DISCUSSION}

Dynamics of the population structures, genetic diversity, and mating systems of continuous versus disjunct sandalwood landraces in 2012-2019

The number of mature and flowering individuals of Bejiharjo decreased from 2012 to 2019. The level of fragmentation did increase, particularly in 2019, during which individual reduction due to illegal logging and land conversion became more extreme. Individuals in more recent years consisted of clonalized stands, as indicated by the finding of fewer distinct genotypes and higher clonality rates, both of which lower the genetic base. The increase in clonality and reduction of the genetic base over time results in increased selfing rates, reduced offspring heterozygosity, and extremely reduced seedling recruitment. Very poor seedling recruitment, which was observed following mass flowering, is considered a result of inbreeding depression (Table 1)

The dynamics of genetic diversity in Bleberan, which was relatively undisturbed, appeared to be highly affected by fluctuations in the parental genetic base (i.e., flowering parents) in each of the flowering seasons considered in this study. The flowering pattern in Bleberan differed from that in Bejiharjo. Most parents of Bleberan demonstrated an irregular flowering pattern in which some parents bore flowers in one flowering season but remained in a vegetative state in the following season. This irregularity of flowering individuals could cause fluctuations in the actual population size, resulting in a different genetic base, mating system, and reproductive outputs every season. The flowering season may be dominated by heterozygotic genotypes, which could broaden the genetic base, increase the outcrossing rate during the season, ad result in offspring with higher heterozygosity and more abundant seedling recruitment. However, when the season is dominated by a group of relatives with homozygotic genotypes, narrowing of the genetic base may increase the inbreeding rate and reduce reproductive outputs. The high heterozygosity of offspring in 2012 (Table 1) may be attributed to a wider genetic base because the flowering season was dominated by unrelated and heterozygotic genotypes (data not shown) despite the small population size. The 2014 flowering season was dominated by more-clonalized parents with identical genotypes (data not shown), which may have increased inbreeding and, in turn, reduced the heterozygosity of their offspring (Table 1) despite the large population size. The highest offspring heterozygosity was observed in 2019 (Table 1) and could be attributed to the wide genetic base available in this season. Indeed, among the years studied, the population size was smallest in this year, but the outcrossing rate remarkably increased because mating occurred between unrelated parents with heterozygotic genotypes.

Table 1. Population structures, seedling recruitment, and genetic parameters of in the Bejiharjo and Bleberan sandalwood landraces in Gunung Sewu during the flowering periods of 2012-2019

\begin{tabular}{|c|c|c|c|c|c|c|c|c|c|c|c|c|}
\hline \multirow{3}{*}{ Year } & \multicolumn{5}{|c|}{ Population structures } & \multirow{3}{*}{$\begin{array}{c}\text { Seedling } \\
\text { recruitment }\end{array}$} & \multicolumn{6}{|c|}{ Genetic parameters } \\
\hline & \multirow{2}{*}{$\begin{array}{c}\text { Mature } \\
\text { indiv. }\end{array}$} & \multirow{2}{*}{ Flowering } & \multirow{2}{*}{$\begin{array}{l}\text { Nep } \\
(\%)\end{array}$} & \multirow{2}{*}{$\begin{array}{c}\text { Distinct } \\
\text { genotypes }\end{array}$} & \multirow{2}{*}{$\begin{array}{c}\text { Clonality } \\
(\%)\end{array}$} & & \multicolumn{2}{|c|}{$\mathbf{H e}$} & \multicolumn{2}{|c|}{ Ho } & \multicolumn{2}{|c|}{$\mathbf{F}_{\text {IS }}$} \\
\hline & & & & & & & Parent & Seedling & Parent & Seedling & Parent & Seedling \\
\hline \multicolumn{13}{|c|}{ Bejiharjo landrace } \\
\hline 2012 & 449 & 80 & 17.82 & 56 & 31.03 & 23 & 0.423 & 0.313 & 0.462 & 0.180 & -0.104 & 0.335 \\
\hline 2014 & 449 & 116 & 25.84 & 69 & 44.83 & 23 & 0.343 & 0.184 & 0.224 & 0.083 & 0.284 & 0.352 \\
\hline 2019 & 364 & 61 & 16.76 & 17 & 72.13 & 31 & 0.321 & 0.196 & 0.249 & 0.124 & 0.130 & 0.304 \\
\hline \multicolumn{13}{|c|}{ Bleberan landrace } \\
\hline 2012 & 1834 & 99 & 5.40 & 88 & 11.00 & 206 & 0.473 & 0.435 & 0.559 & 0.392 & -0.190 & 0.059 \\
\hline 2014 & 1834 & 129 & 7.03 & 70 & 45.74 & 205 & 0.351 & 0.309 & 0.281 & 0.334 & 0.164 & -0.029 \\
\hline 2019 & 1834 & 64 & 3.48 & 58 & 9.38 & 176 & 0.505 & 0.554 & 0.729 & 0.721 & -0.454 & -0.317 \\
\hline
\end{tabular}

Note: $N_{e p}$ : effective population size; He: Hardy-Weinberg expected panmictic heterozygosity; $\mathrm{H}_{\mathrm{o}}$ : observed heterozygosity; Fis: mean fixation index overall loci indicating the extent of deviation from the expected frequencies under Hardy-Weinberg equilibrium 
Table 2. Genetic differentiation (between sites and through generations) and migration rates of two sandalwood landraces

\begin{tabular}{|c|c|c|c|c|c|c|c|}
\hline \multirow{3}{*}{ Year } & \multicolumn{4}{|c|}{ Genetic differentiation through generations } & \multicolumn{2}{|c|}{$\begin{array}{c}\text { Genetic differentiation } \\
\text { between landraces }\end{array}$} & \multirow{3}{*}{$\begin{array}{c}\text { Migration rate }\left(\mathrm{N}_{\mathrm{e}} \mathrm{m}\right) \\
\text { (individuals per generation) }\end{array}$} \\
\hline & \multicolumn{2}{|c|}{ Bejiharjo } & \multicolumn{2}{|c|}{ Bleberan } & \multirow{2}{*}{$\mathrm{D}_{\mathrm{ST}}(\%)$} & \multirow{2}{*}{$\mathrm{G}_{\mathrm{ST}}(\%)$} & \\
\hline & $\mathrm{D}_{\mathrm{ST}}(\%)$ & $\mathrm{G}_{\mathrm{ST}}(\%)$ & $\mathrm{D}_{\mathrm{ST}}(\%)$ & $\mathrm{G}_{\mathrm{ST}}(\%)$ & & & \\
\hline 2012 & 30.45 & 54.12 & 14.64 & 24.38 & 2.20 & 4.87 & 4.89 \\
\hline 2014 & 32.63 & 55.32 & 27.03 & 45.02 & 1.37 & 4.02 & 5.97 \\
\hline 2019 & 30.46 & 54.17 & 8.72 & 14.14 & 9.80 & 18.95 & 1.07 \\
\hline
\end{tabular}

DST: genetic diversity between population; FST $\left(\mathrm{G}_{\mathrm{ST}}\right)$ : mean proportion of total gene diversity in polymorphic loci due to differences between populations; $\mathrm{N}_{\mathrm{e}} \mathrm{m}$ : migration rate

\section{Dynamics of the allele frequencies and distributions of the two sandalwood landraces in 2012-2019}

All six loci (i.e., Est-1, Est-2, Est-3, Dia-1, Dia-2, and $S k d-1)$ are polymorphic in the Bleberan site, and no missing allele was noted in any of the observation years. However, as previously discussed, the irregularity of the flowering patterns in this site caused fluctuations in the actual population size, resulting in variations in the genetic base, mating system, and reproductive outputs in every season. High allelic frequency was observed in 2012 (see Table S1) because the flowering season was dominated by unrelated and heterozygotic genotypes (data not shown) despite the small population size. The increased rarity and loss of missing alleles in the 2014 flowering season (see Table S1) could be attributed to the presence of moreclonalized parents with identical genotypes (data not shown), which could increase inbreeding and reduce the heterozygosity of offspring despite the large population size. The widest genetic base was observed in 2019, and this phenomenon resulted in higher allelic frequencies compared with those in earlier years because of remarkable increases in the outcrossing rate due to mating between unrelated parents with heterozygotic genotypes.

Est-2 is monomorphic in Bejiharjo, where rare and missing alleles are more apparent, particularly at the seedling level. Recent years showed greater alleles loss than previous years. Allele " $a$ " in the Dia-2 locus and allele " $b$ " in the $S k d-1$ locus, which was considered rare in previous years, were missing at the seedling level in 2019. Recent years also consisted of rarer alleles. Some gene flow appeared to have occurred because allele " $a$ " in the Dia-1 locus, which was missing in previous years, was observed in 2019 (see Table S1 for more details).

Small populations are characterized by genetic processes that differ from those of larger ones. Selection is more likely to occur in small fragmented populations than in larger ones, resulting in the increased likelihood of rare and missing alleles because of genetic drifts and the fixation of deleterious alleles. The bottleneck effect and genetic drifts, which may occur as a result of selection events, can be confirmed by the occurrence of rare and missing alleles (Bottin et al. 2007; Garfî et al. 2013; Moreira et al. 2015). Increases in the bottleneck effect and genetic drifts could increase the homozygosity of a landrace. Thus, the higher threat of extinction in fragmented populations is caused by higher levels of inbreeding, which, in turn, affect reproductive fitness and survival.

\section{Differences in genetic differentiation and gene flow between the continuous versus disjunct sandalwood landraces in 2012-2019}

Genetic differentiation between Bejiharjo and Bleberan landraces, along with the increase in fragmentation of Bejiharjo, became more apparent over time. $D_{\mathrm{ST}}$ and $\mathrm{G}_{\mathrm{ST}}$ increased from 2012 to 2019, indicating an increase in genetic differences between the two sites (Table 2). This finding is similar to the case of three populations of $S$. album in Tamil Nadu and Karnataka India, which revealed a genetic difference of $54.9 \%$. Thus, isolated sites may undergo different genetic and reproductive processes or comprise different genotypes (da Silva et al. 2017).

The migration rate between the two landraces, which was measured by calculating $\mathrm{N}_{\mathrm{e}} \mathrm{m}$ in this study, also decreased over time. Bleberan is considered a continuous landrace because it connects to other landraces and ex situ conservation areas by sharing seeds through both biotic agents and streamflow. Sandalwood seeds are widely dispersed by birds, and some seed deposits were found along with riparian sites in this study. A previous study reported a large gene flow between Bleberan and Wanagama (the $\mathrm{N}_{\mathrm{em}}$ of Wanagama and Bleberan is 48 individuals per generation). The low migration rate among landraces, particularly in fragmented ones, such as Bejiharjo and Mulo, may be due to restricted gene flow caused by different landscape and genetic structures (Ratnaningrum et al. 2015).

\section{Designing conservation strategies based on clonality and fragmentation level}

The level of habitat isolation and fragmentation may be affected by multiple scenarios, including the geographic, evolutionary, and anthropogenic history, natural hazardous events, and human activities. The genetic composition of recent parents and landscape structures determine the clonality, mating systems, and gene flow of sandalwood populations, a condition that has led to different levels of reproductive fitness and genetic diversity. Because sandalwood individuals in Gunung Sewu are dominantly outcrossers, clonality and genetic base narrowing considerably reduce their outcrossing rate. A wider genetic base and higher gene flow are important in maintaining the genetic and reproductive processes of sandalwood under equilibrium.

Fragmentation and clonality render sandalwood an endangered species subject to extinction because genetic depletion and poor reproduction reduce the ability of the 
plants to cope with various threats. Despite the presence of and recent increase in sandalwood threats, however, no specific conservation programs aiming to protect fragmented sites in Gunung Sewu have yet been formulated. Hence, Gunung Sewu must be protected under the geopark scheme, in line with integrated conservation activities, to protect this endangered species against specific cases, such as fragmentation, isolation, and clonality.

The main recommendations for preserving and strengthening the sandalwood population in Indonesia focus on maintaining the genetic processes and reproductive events of individual populations by implementing different strategies based on the genetic base, mating preferences, and levels of fragmentation, isolation, and clonality of each landrace. Continuous outbreeding and less-clonalized populations may naturally maintain their genetic process in equilibrium only if the parents prefer sexual regeneration rather than vegetative propagation. In more disjunct, inbred, clonalized, and low-genetic base populations, conservation strategies should focus on improving the genetic base, reducing parental clonality, preventing geitonogamy, enhancing outcrossing opportunities, and facilitating gene flow. Finally, the designed conservation strategies must be integrated with regional and national conservation programs under suitable rehabilitation, reintroduction, and community forestry schemes and conservation management under the geopark scheme.

Several activities to define a conservation strategy are proposed below.

Improving the parental genetic base. Remnant populations should be protected and enriched with select genotypes to support a wider genetic base and outcrossmating system. Regenerating populations by seedling recruitment is another option, particularly for small and fragmented populations. Genetic diversity should be improved by introducing select seedlings from the most appropriate genotypes to enhance reproductive fitness and outcrossing rate (Lhuillier et al. 2006). Genetic infusion with high outcrossers and genetically diverse materials should also be considered to improve the genetic base (Byrne et al. 2003) and outcrossing rate (Lhuillier et al. 2006) of sandalwood. Landraces with higher heterozygosity and crossability, such as Wanagama and Bleberan, may offer suitable genetic material resources. Different genotypes may be introduced to the existing remnant population, but the risks of outbreeding depression should be considered (Bottin et al. 2007; Warburton et al. 2000). The materials for genetic infusion should preferably be collected from local sites, rather than alien provenances, to prevent equilibrium disturbances (Byrne et al. 2003), minimize the risk of outbreeding depression (Bottin et al. 2007; Warburton et al. 2000), and support local adaptation (Bottin et al. 2007).

Preventing parental clonality. The degree of clonality of a landrace depends on the landscape features and degree of population disturbance. Because sandalwood has strong ability to propagate via root suckers, landscape features promoting vegetative propagation, such as rocky and shallow soils, may contribute to the formation of an abundance of root suckers. In this study, most of the root suckers observed developed from wounded roots under natural or anthropogenic events but were inhibited in deep soils. Therefore, landscape management should consider avoiding features that may enhance vegetative propagation, such as rocky soils, and seek optimal methods to prevent clone formation. Several technical methods, such as the removal of root suckers, is also recommended (Lhuillier et al. 2006; Warburton et al. 2000). In addition, root suckers could be replanted under a given plantation program design (Rao et al. 2007).

Facilitating natural generative-seedling recruitment. Population regeneration through natural generativeseedling recruitment is a major management concern, particularly for clonalized, fragmented, and low-genetic base populations. Sexual reproduction could be promoted by stimulating flower production and supporting pollination and fruit development. Natural seedling recruitment could be facilitated by improving seed beds and protecting seeds from disturbances (White et al. 2007). Planting annual legumes to provide a primary host for sandal seedlings and improve the quality of soils is recommended (McKinnel 1993).

Optimizing outcrossing in the population: Flowering, pollinator and pollination management, and outcrossplanting designs. The clonalized landrace in this study produced an abundance of flowers and flowering trees, but most of the latter shared the same parent. Hence, geitonogamy dominated the mating patterns within these clonalized populations, thereby increasing the possibility of inbreeding depression. Considering the factors that may prevent the interspecific pollen flow is important. Mass flowering attracts more pollinators but may also enhance the self-pollination probability of a landrace (Lhuillier et al. 2006; Ratnaningrum et al. 2016, 2017). In this case, the planting and enrichment programs of self-incompatible individuals should consider the parental genetic base and their crossability. However, effort should also be exerted to avoid outbreeding depression, which occurs when crosses are performed between plants from very distant genotypes or floral structures (Warburton et al. 2000; Bottin et al. 2007). Flowering, pollinator, and pollination management and outcross-planting are recommended to promote outcrossing in the sandalwood population.

\section{Flowering management}

Regular flowering may be supported by facilitating artificial flowering stimulation. Flowering can be induced by treatment with hormones, such as GA, combined with several cultivation techniques, including heat, drought, and girdling. Flowering in sandalwood is triggered by hot and dry environments (Ratnaningrum and Indrioko 2015; Ratnaningrum et al. 2016, 2017). Girdling on stems and the basal portions of roots improves flowering but may also induce root sucker formation (Balai Penelitian Kehutanan Kupang, pers. comm.). Enrichment planting using genotypes with good reproductive fitness is another option. This study uncovered the long-term reproductive fitness of the continuous and genetically diverse Bleberan landrace. 
Therefore, this landrace may be recommended as a seed source.

\section{Pollinator and pollination management}

Sandalwood is naturally highly outcrossed and protandrous, with partial or complete self-incompatibly. Therefore, factors that may inhibit outcross-pollination could have considerable effects on the reproduction of the landrace, especially reproductive failure and, thus, reduce reproductive outputs. Natural outcrossing could be supported by managing pollination and pollinators to maintain mating systems contributing to the increase in landrace diversity and prevent inbreeding depression (Garfî et al. 2013; Torres et al. 2003). Flowering stimulation, artificial rewards (i.e.,., sugar solutes; Jones and Little 1983), and artificial nests for pollinators (Garfì et al. 2013) are recommended. Natural pollination could also be supported by creating a suitable habitat for pollinators and their pollination activities. Developing habitat-based conservation and establishing natural corridors are important to connect landscapes (Pautasso 2009; Hmeljevski et al. 2014).

\section{Outcross-planting design}

The outcrossing rate can be improved by introducing the most appropriate genotypes (Lhuillier et al. 2006) and infusing genetically diverse and highly outcrossing materials (Byrne et al. 2003). However, the risks of outbreeding depression should be considered (Bottin et al. 2007; Warburton et al. 2000). Outcross-planting designs should also assess the crossability of each of the available genotypes and variants (see Ratnaningrum et al. 2018 for more detailed information on floral sandalwood variants).

Landscape connectivity: Facilitating gene flow and preventing habitat fragmentation. Gene flow may be facilitated by reintroducing and protecting the appropriate dispersal agents (Lhuillier et al. 2006). Several birds, such as madu sriganti (Nectariana jugularis), puyuh pepekoh (Coturnix chinensis), kutilang (Pycnonotus aurigaster), tekukur (Stretopelia chinensis), and cekakak sungai (Todirhampus chloris), are able to break seed chemicaldormancy and support seed germination in their digestion system and spread seeds over a $5 \mathrm{~km}$ range (Ratnaningrum et al. 2015, 2017). Landscape-based conservation by maintaining and developing natural corridors may also provide refuge and protection to dispersal agents (Pautasso 2009). The concept of biodiversity corridors can be applied when connecting landscapes. Biodiversity corridors refer to areas of vegetation that allow agents to travel between patches of forests. These corridors provide shelter, food, and protection by adopting the diversity and structure of the native vegetation (Hmeljevski et al. 2014).

\section{ACKNOWLEDGMENTS}

This research was supported by a grant from Rekognisi Tugas Akhir for the years 2019 to 2021 by Universitas Gadjah Mada, Yogyakarta, Indonesia. We thank Jito for contributing to the greenhouse work and Untung Maryanto for contributing to the laboratory work. The Heads of the Bejiharjo and Bleberan villages are gratefully acknowledged for granting permission for our field assessment. We are also grateful to the Sandalwood Genetic Conservation Team of the Tree Improvement Laboratory, Universitas Gadjah Mada.

\section{REFERENCES}

Angadi VG, Jain H, Shankaranarayana KH. 2003. Genetic diversity between sandal populations of different provenances in India. Institute of Wood Science and Technology. Bangalore, India.

Bottin L, Tassin J, Nasi R, Bouvet J. 2007. Molecular, quantitative and abiotic variables for the delineation of evolutionarily significant units: case of sandalwood (Santalum austrocaledonicum Vieillard) in New Caledonia. Conserv Genet 8 (1): 99-109. DOI: 10.1007/s10592-0069152-7

Bradbury D, Grayling PM, MacDonald B, Hankinson M, Byrne M. 2015. Clonality, interspecific hybridization and inbreeding in a rare mallee eucalypt, Eucalyptus absita (Myrtaceae), and implications for conservation. Conserv Genet 17 (1): 193-205. DOI: 10.1007/s10592015-0771-8

Brand JE. 1994. Genotypic variation in Santalum album. Sandalwood Research Newsletter.

Byrne M, MacDonald B, Broadhurst L, Brand J. 2003. Regional genetic differentiation in Western Australian sandalwood (Santalum spicatum) as revealed by nuclear RFLP analysis. Theor Appl Genet 107 (7): 1208-1214. DOI: 10.1007/s00122-003-1365-2

da Silva JAT, Kher MM, Soner D, Nataraj M, Dobranszki J, Millar MA. 2017. Santalum molecular biology: molecular markers for genetic diversity, phylogenetics and taxonomy, and genetic transformation. Agrofor Syst 92 (5): 1301-1315. DOI: 10.1007/s10457-017-0075-8

da Silva JA, Kher MM, Soner D, Page T, Zhang X, Nataraj M, Ma G. 2016. Sandalwood: basic biology, tissue culture, and genetic transformation. Planta 243 (4): 847-887. DOI: 10.1007/s00425-0152452-8

Dani KGS, Ravikumar P, Kumar RP, Kush A. 2011. Genetic variation within and among small isolated populations of Santalum album. Biol Plant 55 (2): 323-326. DOI: 10.1007/s10535-011-0046-2

de Abreu Moreira P, Brandao MM, de Araujo NH, de Oliveira DA, Fernandes GW. 2015. Genetic diversity and structure of the tree Enterolobium contortisiliquum (Fabaceae) associated with remnants of a seasonally dry tropical forest. Flora Morph Distrib Funct Ecol Plants 210: 40-46. DOI: 10.1016/j.flora.2014.10.005

Fathin AN, Ratnaningrum YWN. 2018. The differences in floral structure of three sandalwood variants in one of Gunung Sewu (Indonesia) population, and their consequences on visitor diversity and visitation rate. Biodiversitas 19 (3): 1097-1101. DOI: 10.13057/biodiv/d190343

Frankham R, Ballou JD, Briscoe DA. 2002. Introduction to Forest Genetics. Cambridge University Press. Cambridge, UK.

Garfî G, Mercati F, Fontana I, Collesano G, Pasta S, Vendramin GG, Michele R, Carimi F. 2013. Habitat features and genetic integrity of wild grapevine Vitis vinifera L. subsp. sylvestris (C.C. Gmel.) Hegi populations: A case study from Sicily. Flora 208 (8-9): 538-548. DOI: 10.1016/j.flora.2013.08.005

Harbaugh DT, Baldwin BG. 2007. Phylogeny and biogeography of the Sandalwoods (Santalum, Santalaceae): repeated dispersals throughout Pacific. Am J Bot 94 (6): 1028-1040. DOI: 10.3732/ajb.94.6.1028

Haryjanto L, Widowati TB, Sumardi S, Fiani A, Hadiyan Y. 2017. Variation of chemical compounds of sandalwood oil from various provenances in Indonesia. Indo J For Res 11 (1): 77-86. DOI: 10.20886/jpth.2017.11.1.77-86

Hmeljevski KV, Freitas L, Domingues R, Pereira AR, Cancio AS, Andrade AC, Machado MA, Viccini LF, Forzza RC. 2014. Conservation assessment of an extremely restricted bromeliad highlights the need for population-based conservation on granitic inselbergs of the Brazilian Atlantic Forest. Flora 209 (5-6): 250-259. DOI: 10.1016/j.flora.2014.03.004

Indrioko S, Ratnaningrum YWN. 2015. Habitat loss caused clonality, genetic diversity reduction and reproductive failure in Santalum 
album, an endangered endemic species of Indonesia. Proc Environ Sci 28: 613-620. DOI: 10.1016/j.proenv.2015.07.077

IUCN. 1994. IUCN Red List Categories And Criteria: Version 1.2. IUCN species survival commission. international union for conservation of nature and natural resources. Glad, Switzerland, and Cambridge, UK.

IUCN. 2009. IUCN Red List Categories And Criteria: Version 3.1. IUCN species survival commission. international union for conservation of nature and natural resources. Glad, Switzerland, and Cambridge, UK.

Jones CE, Little RJ. 1983. Handbook of Experimental Pollination Biology. Van Nostrand Reinhold Co. Inc. New York.

Klank C, Ghazoul J, Pluess AR. 2012. Genetic variation and plant performance in fragmented populations of globeflowers (Trollius europaeus) within agricultural landscapes. Conserv Genet 13 (3): 873-884. DOI: 10.1007/s10592-012-0337-y

Lhuillier E, Butaud JF, Bouvet JM. 2006. Extensive clonality and strong differentiation in the Insular Pacific tree Santalum insulare: implications for its conservation. Ann Bot 98 (5): 1061-1072. DOI: $10.1093 / \mathrm{aob} / \mathrm{mcl} 190$

Pautasso M. 2009. Geographical genetics and the conservation of forest trees. Perspect Plant Ecol Evol Syst 11 (3): 157-189. DOI 10.1016/j.ppees.2009.01.003

Rao MN, Ganeshaiah KN, Shaanker RU. 2007. Assessing threats and mapping sandal resources to identify genetic 'hot-spot' for in-situ conservation in peninsular India. Conserv Genet 8 (4): 925-935. DOI: 10.1007/s10592-006-9247-1

Ratnaningrum YWN, Kurniawan A. 2019. Floral structure and genetical differences of sandalwood variants in Gunung Sewu (Java, Indonesia), and its effects on breeding systems and reproductive ability. Biodiversitas 20 (2): 393-404. DOI: 10.13057/biodiv/d200213

Ratnaningrum YWN, Indrioko S, Faridah E, Syahbudin A. 2018. Population structures and seasons affected flowering, pollination and reproductive outputs of sandalwood in Gunung Sewu, Java, Indonesia. Nusantara Biosci 10 (1): 2087-3948. DOI: 10.13057/nusbiosci/n100103

Ratnaningrum YWN, Indrioko S, Faridah E, Syahbudin A. 2017. Gene flow and selection evidence of sandalwood under various population structures in Gunung Sewu (Java, Indonesia), and its effect on genetic differentiation. Biodiversitas 18 (4): 1493-1505. DOI: 10.13057/biodiv/d180427

Ratnaningrum YWN, Indrioko S, Faridah E, Syahbudin A. 2015. The effects of population size on genetic parameters and mating system of sandalwood in Gunung Sewu, Indonesia. Indo J Biotech 20 (2): 182201. DOI: $10.22146 /$ ijbiotech.24347

Sampson JF, Byrne M, Gibson N, Yates C. 2016. Limiting inbreeding in disjunct and isolated populations of a woody shrub. Ecol Evol 6 (16): 5867-5880. DOI: $10.1002 /$ ece 3.2322

Sandeep KA, Rodrigues V, Viswanath S, Shukla AK, Sundaresan V. 2019. Morpho-genetic divergence and population structure in Indian Santalum album L. Trees 34 (5): 1113-1129. DOI: 10.1007/s00468020-01963-2

Seido K. 1993. Manual of isozyme analysis. Japan International Cooperation Agency (JICA) and Dirjen RLPS, Departemen Kehutanan Republik Indonesia.

Sindhu-Veerendra HCS, Anantha-Padmanabha HSA. 1996. The breeding system in Sandal (Santalum album L.). Silvae Genet 45 (4): 188-190.

Suma TB, Balasundaran M. 2003. Isozyme variation in five provenances of Santalum album in India. Aust J Bot 51 (3): 243-249. DOI: 10.1071/BT02094

Tamla HT, Cornelius JP, Page T. 2012. Reproductive biology of three commercially valuable Santalum species: development of flowers and inflorescences, breeding systems, and interspecific crossability. Euphytica 184 (3): 323-333. DOI: 10.1007/s10681-011-0530-y

Torres E, Iriondo JM, Perez C. 2003. Genetic structure of an endangered plant, Antirrhinum microphyllum (Scrophulariaceae): allozyme and RAPD analysis. Am J Bot 90 (1): 85-92. DOI: 10.3732/ajb.90.1.85

Warburton CL, James EA, Fripp YJ, Trueman SJ, Wallace HM. 2000. Clonality and sexual reproductive failure in remnant populations of Santalum lanceolatum (Santalaceae). Biol Conserv 96 (1): 45-54. DOI: $10.1016 / \mathrm{S} 0006-3207(00) 00049-5$

Young A, Boshier D, Boyle T. 2000. Forest Conservation Genetics: Principles and Practices. CSIRO Publishing, Collingwood, Australia. DOI: $10.1079 / 9780851995045.0000$ 
Table S1. Allelic frequencies at each loci of two sandalwood landraces in Gunung Sewu in 2012-2019

Bejiharjo Landrace

\begin{tabular}{|c|c|c|c|c|c|c|c|c|}
\hline \multirow{2}{*}{ Year } & \multirow{2}{*}{ Generation } & \multirow[b]{2}{*}{ Allele } & \multicolumn{6}{|c|}{ Loci } \\
\hline & & & Est-1 & Est-2 & Est-3 & Dia-1 & Dia-2 & Shd-1 \\
\hline \multirow[t]{8}{*}{2012} & Parents & $\mathrm{a}$ & 0.188 & 0.500 & 0.731 & 0.019 & 0.082 & 0.652 \\
\hline & & $\mathrm{b}$ & 0.813 & 0.500 & 0.269 & 0.744 & 0.715 & 0.116 \\
\hline & & $\mathrm{c}$ & & & & 0.237 & 0.203 & 0.232 \\
\hline & & HS & 0.305 & 0.500 & 0.393 & 0.390 & 0.441 & $\mathbf{0 . 5 0 7}$ \\
\hline & Seedlings & $\mathrm{a}$ & 0.043 & 0.804 & 0.739 & 0.000 & 0.043 & 0.658 \\
\hline & & $\mathrm{b}$ & 0.957 & 0.196 & 0.261 & 0.841 & 0.804 & 0.105 \\
\hline & & $\mathrm{c}$ & & & & 0.159 & 0.152 & 0.237 \\
\hline & & HS & 0.083 & 0.315 & 0.386 & 0.268 & 0.328 & 0.500 \\
\hline \multirow[t]{8}{*}{2014} & Parents & $\mathrm{a}$ & 0.082 & 0.813 & 0.849 & 0.022 & 0.122 & 0.625 \\
\hline & & $\mathrm{b}$ & 0.918 & 0.187 & 0.151 & 0.754 & 0.717 & 0.093 \\
\hline & & $\mathrm{c}$ & & & & 0.224 & 0.161 & 0.282 \\
\hline & & HS & 0.150 & 0.304 & 0.256 & 0.380 & 0.445 & 0.521 \\
\hline & Seedlings & $\mathrm{a}$ & 0.022 & 1,000 & 0.957 & 0.000 & 0.022 & 0.737 \\
\hline & & $\mathrm{b}$ & 0.978 & 0.000 & 0.043 & 0.848 & 0.804 & 0.026 \\
\hline & & $\mathrm{c}$ & & & & 0.152 & 0.174 & 0.237 \\
\hline & & HS & 0.043 & 0.000 & 0.083 & 0.258 & 0.322 & 0.400 \\
\hline \multirow[t]{8}{*}{2019} & Parents & $\mathrm{a}$ & 0.025 & 0.672 & 0.902 & 0.074 & 0.066 & 0.656 \\
\hline & & $\mathrm{b}$ & 0.975 & 0.328 & 0.098 & 0.664 & 0.852 & 0.156 \\
\hline & & $\mathrm{c}$ & & & & 0.262 & 0.082 & 0.189 \\
\hline & & HS & 0.048 & 0.441 & 0.177 & 0.485 & 0.262 & 0.510 \\
\hline & Seedlings & $\mathrm{a}$ & 0.113 & 0.839 & 0.919 & 0.032 & 0.000 & 0.887 \\
\hline & & $\mathrm{b}$ & 0.887 & 0.161 & 0.081 & 0.887 & 0.919 & 0.000 \\
\hline & & $\mathrm{c}$ & & & & 0.081 & 0.081 & 0.113 \\
\hline & & HS & 0.200 & 0.271 & 0.148 & 0.206 & 0.148 & 0.200 \\
\hline
\end{tabular}

Bleberan Landrace

\begin{tabular}{|c|c|c|c|c|c|c|c|c|}
\hline \multirow{2}{*}{ Year } & \multirow{2}{*}{ Generation } & \multirow{2}{*}{ Allele } & \multicolumn{6}{|c|}{ Loci } \\
\hline & & & Est-1 & Est-2 & Est-3 & Dia-1 & Dia-2 & Shd-1 \\
\hline \multirow[t]{8}{*}{2012} & Parents & $\mathrm{a}$ & 0.404 & 0.742 & 0.551 & 0.025 & 0.232 & 0.328 \\
\hline & & b & 0.596 & 0.258 & 0.449 & 0.727 & 0.677 & 0.141 \\
\hline & & $\mathrm{c}$ & & & & 0.247 & 0.091 & 0.530 \\
\hline & & HS & 0.482 & 0.382 & 0.495 & 0.409 & 0.480 & 0.591 \\
\hline & Seedlings & $\mathrm{a}$ & 0.223 & 0.847 & 0.595 & 0.084 & 0.184 & 0.515 \\
\hline & & $\mathrm{b}$ & 0.777 & 0.153 & 0.405 & 0.781 & 0.592 & 0.129 \\
\hline & & $\mathrm{c}$ & & & & 0.135 & 0.223 & 0.357 \\
\hline & & HS & 0.347 & 0.259 & 0.482 & 0.365 & 0.565 & 0.591 \\
\hline \multirow[t]{8}{*}{2014} & Parents & $\mathrm{a}$ & 0.388 & 0.787 & 0.612 & 0.016 & 0.178 & 0.337 \\
\hline & & $\mathrm{b}$ & 0.612 & 0.213 & 0.388 & 0.721 & 0.760 & 0.116 \\
\hline & & $\mathrm{c}$ & & & & 0.264 & 0.062 & 0.547 \\
\hline & & HS & 0.475 & 0.335 & 0.475 & 0.411 & 0.387 & 0.574 \\
\hline & Seedlings & a & 0.237 & 0.995 & 0.666 & 0.019 & 0.073 & 0.584 \\
\hline & & $\mathrm{b}$ & 0.763 & 0.005 & 0.334 & 0.758 & 0.924 & 0.054 \\
\hline & & $\mathrm{c}$ & & & & 0.223 & 0.003 & 0.362 \\
\hline & & HS & 0.361 & 0.010 & 0.445 & 0.375 & 0.140 & 0.525 \\
\hline \multirow[t]{8}{*}{2019} & Parents & $\mathrm{a}$ & 0.461 & 0.664 & 0.383 & 0.016 & 0.219 & 0.359 \\
\hline & & $\mathrm{b}$ & 0.539 & 0.336 & 0.617 & 0.641 & 0.648 & 0.188 \\
\hline & & $\mathrm{c}$ & & & & 0.344 & 0.133 & 0.453 \\
\hline & & HS & 0.497 & 0.446 & 0.473 & 0.471 & 0.514 & 0.630 \\
\hline & Seedlings & $\mathrm{a}$ & 0.463 & 0.693 & 0.580 & 0.213 & 0.239 & 0.287 \\
\hline & & b & 0.537 & 0.307 & 0.420 & 0.395 & 0.520 & 0.429 \\
\hline & & $\mathrm{c}$ & & & & 0.392 & 0.241 & 0.284 \\
\hline & & HS & 0.497 & 0.425 & 0.487 & 0.645 & 0.614 & 0.653 \\
\hline
\end{tabular}

rare alleles

: missing alleles 